\author{
Marquette University \\ e-Publications@Marquette
}

Center for Teaching and Learning Research and

Publications

Provost, Office of

2011

\title{
Using Games in Software Engineering Education to Increase Student Success and Retention
}

C. Shaun Longstreet

Marquette University, christopher.longstreet@marquette.edu

Kendra M. L. Cooper

University of Texas at Dallas

Follow this and additional works at: https://epublications.marquette.edu/ctl_leadership

\section{Recommended Citation}

Longstreet, C. Shaun and Cooper, Kendra M. L., "Using Games in Software Engineering Education to Increase Student Success and Retention" (2011). Center for Teaching and Learning Research and Publications. 12.

https://epublications.marquette.edu/ctl_leadership/12 


\title{
Using Games In Software Engineering Education To Increase Student Success And Retention
}

\author{
C. Shaun Longstreet \\ Center for Teaching and Learning, Marquette University \\ Milwaukee, WI \\ Kendra L. Cooper \\ Department of Computer Science, The University of Texas at Dallas \\ Richardson, TX
}

\begin{abstract}
Summary form only given. Spoken language technologies have reached enough maturity to be integrated in many applications in eHealth and eLearning. The challenges and the potential are enormous. There are many other areas in which this claim could be equally made, but these two areas share many technical issues and, of course, they also share a huge significance from a social point of view. This was the driving force for our recent efforts at the Spoken Language Systems Lab of INESC-ID in terms of eHealth and eLearning. This talk tries to give an overview of these efforts and, in spite of the fact that they will be demonstrated for the Portuguese language, it will also try to emphasize how easily they can be extended to new languages.
\end{abstract}


NOT THE PUBLISHED VERSION; this is the author's final, peer-reviewed manuscript. The published version may be accessed by following the link in the citation at the bottom of the page.

\section{SECTION 1.}

\section{Summary}

Creating a game for students creates an interactive student-centered environment rather than a passive content-centered environment. This allows students to create a personalized learning experience, progressively incorporating new knowledge and scaffolding it into what they already know. The variability within this interactive environment permits students to work on lower-level tasks repeatedly as they begin to develop broader analytical skills and make progress towards completing the game objectives. Because each student is able to engage course-based material at his or her own pace, underprepared or at-risk students can focus on needed skills at their convenience. Feedback is frequent and immediate, thereby reinforcing mastery of fundamental skills required for advancing further into the game.

A game is task-oriented rather than content focused; it encourages practice and mastery rather than rote memorization. Games stress strategic learning allowing students to practice further transference of their knowledge to more complex scenarios. Creating a game environment for the SE curriculum creates a highly motivating environment. A realtime strategy game appeals to a student's sense of fantasy and amusement; it is selfdirected, appealing to a student's curiosity; and it is a continuous challenge where existing tasks or knowledge appear incomplete, inconsistent or incorrect, thereby challenging a student to continue and foster deeper levels of learning.

The creation of a real-time strategy game has a better chance of increasing the efficacy of attaining SE student learning outcomes. The rules of the game are designed to mimic the rhetoric and practices of SE as a discipline, thereby engaging players to develop mindsets they can use in professional contexts. The paradigm shift gaming creates will augment faculty resources and will help students become life-long learners, practice deeper problem-solving skills, and enhance their ability to communicate about SE in a professional context. Because the game environment will better motivate students to repeatedly practice outside of class time and challenges them to improve where they specifically have a need, under-represented and higher-risk students will have better chances of success in SE courses. 